\title{
PATENCY FAILURES IN MICROVASCULAR PROSTHETIC GRAFTS
}

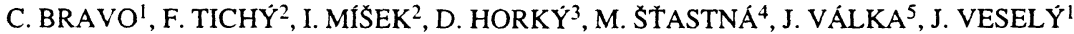 \\ ${ }^{1}$ Department of Plastic Surgery, Faculty of Medicine, Masaryk University, Brno, Czech Republic \\ 2 Department of Anatomy, Histology and Embryology, Faculty of Veterinary Medicine, University of Veterinary \\ an Pharmaceutical Sciences, Brno, Czech Republic \\ ${ }^{3}$ Department of Histology and Embryology, Faculty of Medicine, Masaryk University, Brno, Czech Republic \\ ${ }^{4}$ Institute of Knitting Research, Brno, Czech Republic \\ ${ }^{5}$ Laurea Clinic, Brno, Czech Republic
}

Received November 4, 1996

Accepted November 4, 1997

\begin{abstract}
Bravo C., F.Tichý, I. Míšek, D. Horký, M.Śtastná, J.Válka, J. Veselý: Patency Failures in Microvascular Prosthetic Grafts. Acta vet. Brno, 1997, 66:183-188.

Thirty knitted prosthetic grafts (calibre $2 \mathrm{~mm}$, length $10 \mathrm{~mm}$ ) of three different types were implanted into abdominal aorta of Wistar rats. The types were as follows: Type $1(n=10)$, multifilamentous Dacron coated with polyurethane; Type $2(n=10)$, monofilamentous Dacron coated with polyurethane; type $3(n=10)$ multifilamentous Dacron coated with polylactide. The patency rates of the grafts were $10 \%$ after 1 month, and $0 \%$ after 2 months. The prostheses proved unworkable owing to high incidence of acute thrombosis, lack of endothelium formation, chondrification, and formation of collateral blood sinuses.
\end{abstract}

Microsurgen: graft, structure, vessel, experimental medicine

The implantation of large vascular prostheses has become a routine surgical procedure during the past thirty years ( $\mathrm{B}$ artoš 1994; Firt et al. 1991). No vascular prostheses satisfying the topical requirements of microsurgery are available at present, however.

Since the first experimental implantation of a vascular micro-prosthesis ( M a t s u mo to et al. 1973), many authors were trying to design a functional small-calibre prosthesis, but their attempts did not go beyond the experimental phase (Weinstein et al. 1981; Ganske et al. 1982; Nordestgaard 1986; Nichter and Bindiger 1988). Currently, the smallest calibre of prosthetic grafts used in the clinical practice is $4 \mathrm{~mm}$ (Hess 1985). The major factors responsible for the failure of such implants were a high thrombogenicity and poor healing.

During the past two years, we have developed, in collaboration with the Institute of Knitting Research. Brno, 45 knitted vascular prostheses with a calibre of $2 \mathrm{~mm}$ and have tested them in laboratory rats. A number of the prostheses were not implantable owing to their mechanical properties, such as hardness, fragility and/or insufficient elasticity.

This paper presents results of implantation of three types of knitted vascular prostheses.

\section{Material and Methods}

Thirty five male Wistar rats weighing 400-450 g were used. The animals were anaesthetised by subcutaneous administration of ketamin \& xylazine ( $100 \mathrm{mg}$ and $16 \mathrm{mg}$ per $\mathrm{kg}$ live body mass, respectively). The implantations were done under clean. but not sterile conditions. After skin shaving and desinfection with jodisol, the abdominal cavity was opened by a midline incision and the abdominal aorta was carefully exposed and fixed between the left renal artery and aortic bifurcation. Then the lumbar branches were ligated and the aorta was closed with two bulldog clamps. The aorta was severed and the ends were allowed to retract to facilitate the implantation without any tissue resection. The grafts were immersed in Ringer solution containing heparin prior to the implantation and the aortic stumps were washed with the same solution. A $10 \mathrm{~mm}$ length of the prosthesis with a calibre of $2 \mathrm{~mm}$ was placed as an interposition graft using the spatulating technique ( O'B rien et al. 1984) to accommodate to the slightly 
larger diameter of the prosthesis. Both anastomoses, first the proximal and then the distal, were completed with a running $8 / 0$ suture (Mirafil). The distal clamp was removed after finishing the sutures and blood back flow was checked using the two-forceps technique ( $\mathrm{H}$ a y hurst and O' B ri en 1975). Some blood usually leaked through the stitch holes, but the bleeding ceased rapidly and the proximal clamp could be removed within several minutes, the mean clamping time being 30 minutes. Careful microvascular technique was used and no antibiotics or anticoagulants were administered. All animals in which technical errors occurred during the surgery were eliminated from the experiment.

Implantation of thirty grafts with a calibre of $2 \mathrm{~mm}$ were completed. The rats were divided into four groups: group $1(n=10)$ received prostheses made of multifilamentous, polyurethane-coated Dacron; group $2(n=10)$ received prostheses made of monofilamentous, polyurethane-coated Dacron; group $3(n=10)$ received prostheses made of multifilamentous, polylactide-coated Dacron, acute ligature of the abdominal aorta between the left renal artery and bifurcation was applied in group $4(n=5)$ serving as controls (Tab. 1$)$.

Table 1

\begin{tabular}{|l|c|c|c|c|}
\hline Group & Material & $\begin{array}{c}\text { Superficial } \\
\text { adjustment }\end{array}$ & $\begin{array}{c}\text { Size } \\
\text { of pores } \\
(\mu \mathrm{m})\end{array}$ & $\begin{array}{c}\text { Wall } \\
\text { thickness } \\
(\mu \mathrm{m})\end{array}$ \\
\hline $1(\mathrm{n}=10)$ & $\begin{array}{c}\text { Dacron } \\
\text { (Multifilamentous) }\end{array}$ & Polyurethane & 100 & $100-120$ \\
\hline $2(\mathrm{n}=10)$ & $\begin{array}{c}\text { Dacron } \\
\text { (Monofilamentous) }\end{array}$ & Polyurethane & $10-15$ & 150 \\
\hline $3(\mathrm{n}=10)$ & $\begin{array}{c}\text { Dacron } \\
\text { (Multifilamentous) }\end{array}$ & Polylactide & 100 & $100-120$ \\
\hline $4(\mathrm{n}=5)$ & \multicolumn{2}{|c|}{$\begin{array}{c}\text { Acute ligature of the abdominal aorta between } \\
\text { the left renal artery and bifurcation }\end{array}$} \\
\hline
\end{tabular}

All the rats were examined daily and patency of the grafts was checked in surviving animals by re-laparotomy, visual inspection and the two-forceps technique one and two months after the surgery. Samples for histological examination were collected on post-implantation days 1 and 2 in groups 1 and 3 , and on days $7,11,18,32,62$, and 90 in group 2 . The prostheses were removed, flushed with saline, fixed in $2 \%$ phosphate-buffered glutaraldehyde and prepared according to routine histological methods for examination by light, transmission (TEM) and scanning (SEM) electron microscopy.

\section{Clinical findings}

\section{Results}

All the grafts were patent after the release of the clamps. However, thrombosis and occlusion developed rapidly during the first days after the implantation in groups 1 and 3 (Plate XVI., Fig. 1). The rats showed impaired function of hind legs and died 1-3 days after the surgery. The patency rates were $10 \% 1$ month after the implantation and $0 \%$ two months later. In group 2, the implantation of the prostheses was extremely difficult owing to their hardness and poor elasticity, but the development of thrombi was slower.

The patency rates were $10 \%$ and $0 \%$ one and two months after the implantation, respectively (Tab. 2). Four of the five rats in group 4 died within three days after the acute ligature of the abdominal aorta. In the only survivor limb hind ulcerations were observed twenty days after the operation (Plate XVI., Fig. 2).

\section{Histology}

\section{Groups 1 and 3}

a/ Light microscopy

Histological patterns of the prostheses removed on days 1 and 2 were identical. The prostheses were occluded by mass of erythrocytes mass with irregular islets of fibrin. The 
Table 2

\begin{tabular}{|c|c|c|c|c|c|}
\hline \multirow{2}{*}{ Group } & \multicolumn{5}{|c|}{ \% patent prostheses after implantation } \\
\cline { 2 - 6 } & 1 day & 2 days & 3 days & 1 month & 2 months \\
\hline $1(n=10)$ & 50 & 20 & 10 & 10 & 0 \\
\hline $2(n=10)$ & 100 & 70 & 70 & 10 & 0 \\
\hline $3(n=10)$ & 40 & 10 & 10 & 10 & 0 \\
\hline
\end{tabular}

amount of fibrin in the thrombus decreased towards the caudal anastomosis. Solitary aggregates of lymphocytes were also seen. The outside surface of the prosthesis was covered by a thin layer of loose connective tissue containing numerous leucocytes and macrophages.

\section{b/ Scanning electron microscopy}

The thrombus was apparently asymmetrical with major part on its ventral side and exceeded the cranial suture reaching into the aortic lumen. A thin, discontinuous channel surrounded by erythrocyte aggregates persisted in some segments of the thrombus.

c/ Transmission electron microscopy

The pattern corresponded to findings in the early removed prostheses of group 2 .

\section{Group 2}

a/ Light microscopy

The lumen of the prosthesis collected on day 7 was occluded by a thrombus consisting of platelet aggregates in a connective tissue scaffold. The number of erythrocytes in the thrombi decreased with time and only platelets were seen in the thrombus on day 32 . At that time, groups of fibroblasts surrounded by bundles of fine fibres were found on the inside surface. On day 62 , the surface was formed by a dark membrane-like layer with solitary fusiform cells and groups of leucocytes covered by the mass of the organized thrombus (Plate XVII., Fig. 4)

Progressive proliferation of connective tissue pervaded by numerous blood vessels formed a capsule around the prosthesis. From day 18, this capsule acquired fibrous character and hyalinized areas, and groups of chondroblasts like cells were apparent from day 32 (Plate XVII., Fig. 3). Slit-shaped blood sinuses providing collateral circulation developed between the capsule and the prosthesis. The sinuses were lined by a continuous layer of dark flat cells (Fig. 3) and their walls were pervaded by abundant vessels and lymphocyte infiltrates and, on day 90, also by areas of chondroid tissue (Plate XVIII., Fig. 5).

\section{b/ Scanning electron microscopy}

It was apparently from SEM that the thrombus was limited only to the prosthetic segment. After mechanical removal of the thrombus, the inside surface of the prosthesis was covered by firmly adhering rests of a platelet mass (Plate XIX., Fig. 6).

Both the outside surface of the prosthesis and the adjacent surface of the capsule were covered by containing smooth layer solitary leucocytes. Numerous small vessel stems opened into the blood sinuses. The interface between the aortal and the prosthesis inside surface was always distinguishable (Plate XX., Fig. 7).

c/ Transmission electron microscopy

The ultrastructure of the prosthesis inside surface and the occluding thrombus was rather 
varied. Common components were leukocytes and cells with a large number of cytoplasmatic vesicles and many multiform projections on their surface (Plate XXI., Fig.8).

A thin layer of tenuous connective tissue and fibroblasts arranged into several layers was seen on day 32 (Plate XXII., Fig.9). These signs of onset of organization were no more found on days 62 and 90 .

\section{Discussion}

Although the replacement of larger blood vessels with synthetic prostheses has become a routine surgical procedure, no satisfactory small-calibre arterial prostheses are available. Since 1973, many authors have been conducting experiments with small-calibre prosthetic grafts made of various materials including polytetrafluoroethylene (Masumoto et al. 1973; Weinstein et al. 1981; Ganske et al. 1982; Nordestgaard et al. 1986; $\mathrm{Nichter}$ and Bindinger 1988), polyurethane (Hess et al. 1991), silicone (Joos and S andra 1990) and D a cron (Brie ler et al. 1982), but their results were unsatisfactory. Also the first series of our knitted vascular microprostheses proved unworkable as evidenced by zero patency within two months after the implantation. The reasons of the failure consisted in a higher thrombogencity, poor healing and extensive perivascular fibrosis.

The thrombosis appeared immediately after contact of blood with the prosthetic material. The thrombogenicity of the material stimulates adhesion and degranulation of platelets followed by release of adenosine diphosphate (ADP). The latter, in turn, induces an explosive second-wave platelet aggregation. Fibrin is deposited in the growing thrombus until the lumen of the prosthesis is occluded ( $\mathrm{Grabow}$ k i et al. 1977).

Another possible factor responsible for the early thrombosis of the grafts in groups 1 and 3 was the higher wall porosity. Larger pores allow the penetration of blood into and its immobilization and coagulation in the graft interstices. This results in a poor interface between the blood flow and the wall leading to early thrombosis and occlusion ( $\mathrm{Ca} \mathrm{m} \mathrm{p} \mathrm{bell}$ et al. 1975).

While the pore size of the prostheses implanted in groups 1 and 3 was $100 \mu \mathrm{m}$, the prostheses implanted in group 2 had a pore size range of $10-15 \mu \mathrm{m}$. Seventy percent of the prostheses implanted in group 2 thrombosed later than the prostheses implanted in groups 1 and 3.

Considering the biological adaptability, patency rate and reendothelization the rat is an excellent, reproducible and economical experimental model for the screening of novel microvascular prostheses (Hess et al. 1985). As demonstrated in an earlier communication, NZW and Chin rabbits are not suitable for experimental implantation of microvascular prostheses into the carotid artery owing to vasoconstrictive reactions and early occlusion of the implants ( Hess et al. 1991).

Unlike the opinion of other authors ( $\mathrm{H}$ es s et al. 1984, 1987). hind limb paralysis proved to be a reliable indicator of acute graft thrombosis in our experiments. Similar clinical patterns, including hind limb paralysis, wax pallor of extremities and death due to metabolic disorders within 3 days after the surgical intervention, were observed both in the rats affected by acute graft thrombosis and those with acute ligatures of the abdominal aorta and all its lumbar branches (group 4). The only survivor of group 4 developed hind limb ulceration on day 20. Similar results were reported by Nordestga ard et al. (1986) using a different laboratory model. The formation of the collateral blood sinuses around the graft apparently helped in the blood supply to the caudal body parts.

Occlusions of microvascular prostheses were described by several authors (W e in ste in et al. 1981; Lanzeta and Owen 1993, and others). However, no reference to the development of blood sinuses allowing collateral circulation was found in available 
literature. As demonstrated in our experiments, the sinuses were lined by a layer of endothelium-like cells. If the concept of progressive regeneration of endothelium in prosthetic grafts, postulated by some authors (Hertzer 1981), is true, we assume that the development of endothelium begins with the differentiation of connective tissue cells coming into contact with the blood stream. Our finding of irregular areas of chondroid tissue in the fibrous capsule is remarkable. We regard them as reinforcing structures developing in places of a higher mechanical stress.

Like other authors (We in ste in et al. 1981), we observed progressive changes in the structure of thrombi that are interpreted as a process of quantitative organization involving particularly fibrous structures (collagen tissue). It should be noted that the thrombi developed only in the prosthetic segment not exceeding its either cranial or caudal end. It can therefore be concluded that collateral circulation developed only between the two sutures.

While the grafts used in groups 1 and 3 failed rapidly owing to thrombosis, those used in group 2 remained patent for a time sufficient for the development of collateral circulation.

$\mathrm{Cu}$ adros (1984) reported best patency of prosthetic grafts when sterile technique was used in the implantation. In our experiments, clean, but not sterile technique was used and we did not find signs of infection in any of the animals. The competence of the rat immune system is exceptional as confirmed in our previous experiments, in which two loopfuls of Staphylococcus aureus or Pseudomonas aeruginosa cultures were necessary to induce signs of infection in two rats ( B ravo et al. 1995).

Although rather scarce, data on small-calibre textile vascular prostheses seem to be promising (Jerusalem et al. 1987; Gorbunow and Lebiediew 1988). Further studies will be necessary to improve patency rates of such prostheses.

\section{Nefunkční mikrovaskulární cévní náhrady}

U laboratorního potkana kmene Wistar bylo provedeno na břišní aortě 30 typů implantací 3 typů rozdílných pletených mikrovaskulárních cévních náhrad o vnitřním průměru $2 \mathrm{~mm}$ a délky $10 \mathrm{~mm}$. Náhrady byly rozděleny do 3 skupin: skupina 1 ( $n=10$, náhrady z dacronu mnohovláknité, s povrchovým krytím polyurethanem), skupina $2(n=10$, náhrady $z$ dacronu - mnohovláknité, s povrchovým krytím polyurethanem), skupina $3(n=10$, náhrady $\mathrm{z}$ dacronu - mnohovláknité, s povrchovým krytím polylactidem). Kontrolní skupina byla označena jako 4 . Průchodnost všech náhrad po 1 měsíci byla $10 \%$ a po 2 měsících $0 \%$. Nefunkčnost testovaných náhrad byla provázena akutní trombózou, absencí endotelu, chondrifikací a formováním kolaterálních kanálů.

\section{Acknowledgements}

This work was supported by the Ministry of Health CR (grant IGA MZ CR 4301-3) and the Ministry of Industry and Trade CR (grant MP-3320/09/96).

\section{References}

BARTOŚ. J. 1994: Komplikace a reoperace po rekonstrukčních cévních operacích. Grada-Avicenum, Prague (in Czech)

BRAVO.C.. ONDROVCIIK. P.. V.ALKA. J. 1995: Investigation of the effect of the most frequently used solutions and ointments in common surgical practice. Rozh. Chir. 74:273-276

BRIELER. H. S.. THIEDE. A.. BECK. CH. 1982: Monocytogenic endothelialization in Dacron grafts. J. Cardiovasc. Surg. 23: 483-489

BRIE.N, C. J. O.. VELKOL. D.. H.ARRIS. J. P.. MAY, J. 1984: One milimetre polytetrafluoroethylene (Gore-Tex) as a microvascular prosthesis: Technique and early patency. Aust. N. Z. J. Surg. 54: 469-476 
CAMPBELL, CH. D., GOLDFARB, D., ROE, R. 1975: A small arterial substitute: expanded microporous polytetrafluoroethylene: patency versus porosity. Ann. Surg. 182: 138-143

CUADROS, C. L. 1984: One hundred percent patency of one-milimeter polytetrafluoroethylene (Gore-Tex) grafts in the carotid arteries of rats. Microsurgery $5: 1-11$

FIRT, P., HEJNAL, J., VANĚK, I. 1991: Cévní chirurgie. Avicenum, Prague

GANSKE, J. G., DEMUNTH, R. J., MILLER, S. H., BUCK, D. C., DOLPH, J. L. 1982: Comparison of expanded polytetrafluoroethylene microvascular grafts to autogenous vein grafts. Plast. Reconstr. Surg. 70: 193-201

GORBUNOW, G. N., LEBIEDIEW, L. W. 1988: Vascular prosthesis made of polyester threads in microsurgery. Polim Med. 4: 245-253

GRABOVSKI, E. F., DIDISHEIM, P., LEWIS. J. C., FRANTA, J. T., STROPP, J. Q. 1977: Platelet adhesion to foreign surfaces under controlled conditions of whole blood flow: human vs. rabbit, dog, calf, sheep, pig, macaque, and baboon. Trans. Am. Soc. Artif. Int. Organs. 23: 141-150

HAYHURST, J. W., O'BRIEN, B. 1975: An experimental study of microvascular technique, patency rates and related factors. Br. J. Plast. Surg. 28: 128

HERTZER, N. R. 1981: Regeneration of endothelium in knitted and velour Dacron vascular grafts in dogs. J. Cardiovasc. Surg. 22: 223-230

HESS, F. 1985: History of (micro)vascular surgery and the development of small-caliber blood vessel prostheses (with some notes on patency rates and re-endothelialization). Microsurgery 6: 59-69

HESS, F., JERUSALEM, C., BRAUN, B., GRANDE, P. 1984: Patency and neo-intima development in 10-cmlong microvascular polyurethane prostheses implanted into the rat aorta. Thorac. Cardiovasc. Surg. 32: 283-287

HESS, F., JERUSALEM, C., BRAUN, B., GRANDE, P. 1985: Three years experience with experimental implantation of fibrous polyurethane microvascular prostheses in the rat aorta. Microsurgery 6: 155-162

HESS, F., STEEGHS, S., JERUSALEM, CH., BRAUN, B., GRANDE, P. 1991: Failure to obtain long-term patency after implantation of fibrous polyurethane prostheses in the carotid arteries of rabbits. Microsurgery 12: 164-167

HESS, F., STEEGHS, S., JERUSALEM, C., WIJN, P., SKOTNICKI, S. 1987: Determination of the patency of vascular prostheses implanted in the rat aorta by means of ultrasonic blood-flow measurements. Microsurgery 8: $5-10$

JERUSALEM, C., HESS, F., WERNER, H. 1987: The formation of a neo-intima in textile prostheses implanted in the aorta of rats and dogs. Cells Tissue Res. 248: 505-510

JOOS, K. M., SANDRA, A. 1990: Microarterial synthetic graft repair: interstitial cellular components. Microsurgery 11: 268-277

KRAG, CH., HOLCK, S. 1981: The value of the patency test in microvascular anastomosis: Correlation between observed patency and size of intraluminal thrombus: An experimental study in rats. Br. J. Plast. Surg. 34:64-66

LANZETTA, M., OWEN, E. R. 1993: Use of the 3M precise microvascular anastomotic system in grafting 1-mm diameter arteries with polytetrafluoroethylene prostheses: a long-term study. J. Reconstr. Microsurg. 9:173-181

MATSUMOTO, H., HASAGAWA, T., FUSE, K., YAMAMOTO, M., SAIGUSA, M. 1973: A new vascular prosthesis for a small caliber artery. Surgery 74: 519-523

NICHTER, L. S., BINDIGER, A. 1988: Improving micrograft patency. Microsurgery 9: 235-241

NORDESTGAARD, A. G., BUCKELS, J. A. C.. WILSON, S. C. 1986: A laboratory model for the evaluation of tromboembolic complications of small-diameter vascular prostheses. Br. J. Exp. Pathol. 67: 839-849

WEINSTEIN,P. R., REINERT,R. L., BRITTALN, F: 1981: Delayed trombosis of synthetic microvascular bypass grafts. Neurosurgery 9: 268-274

Address for correspondence:

Doc. MVDr. F. Tichý, CSc.

Department of Anatomy, Histology and Embryology

Faculty of Veterinary Medicine

University of Veterinary and Pharmaceutical Sciences

Palackého 1-3

61242 Brno

Czech Republic

Phone: (420) 541562200 